\title{
JPEB
}

Jurnal Penelitian Ekonomi dan Bisnis, 2 (1), 2017, Hal : 32 - 45

http://www.jpeb.dinus.ac.id

\section{ANALISIS KEPUASAN KONSUMEN PT. HEXPHARMJAYA DI KARESIDENAN PEKALONGAN}

\author{
Agus Setyawan* \\ Magister Manajemen, Fakultas Ekonomi dan Bisnis, Universitas Dian Nuswantoro \\ Jalan Imam Bonjol Nomor 207 Semarang 50131, Indonesia \\ *Corresponding Author: Agussety@yahoo.com
}

Diterima : November 2016; Direvisi : Januari 2017; Dipublikasikan : Maret 2017

\begin{abstract}
This study aimed to determine the effect of drug price reductions, service, corporate image, and distribution of drugs in PT. Hexpharmjaya on consumer satisfaction Se-Karisidenan Pekalongan. In order to know the influence of independent variables on the dependent variable are either partially or simultaneously need to do research using survey recent research using quantitative approach. The population in this study is a physiciankarisidenan se Pekalongan become customers or prescribe drugs from PT. Hexpharmjaya. The research data will be collected by interview and questionnaire. Analysis of the data to test the hypothesis is multiple regression analysis, hypothesis testing, and analysis of the coefficient of determination. The results of the study prove that there is a significant effect of decreasing the price of drug services and corporate image at PT. Hexpharmjaya on consumer satisfaction in Pekalongan Residency and there is no significant influence on drug distribution at PT. Hexpharmjaya towards Consumer Satisfaction in Karisidenan Pekalongan. The results of the study prove that there is a significant effect of decreasing the price of drug services and corporate image at PT. Hexpharmjaya on consumer satisfaction in Pekalongan Residency and there is no significant influence on drug distribution at PT. Hexpharmjaya towards Consumer Satisfaction in Karisidenan Pekalongan.
\end{abstract}

Keywords: decreasing the proce of drug; service; corporate image; Satisfaction

\begin{abstract}
ABSTRAK
Penelitian ini bertujuan untuk mengetahui pengaruh penurunan harga obat, pelayanan, citra perusahaan, dan distribusi obat pada PT. Hexpharmjaya terhadap Kepuasan konsumen Se-Karisidenan Pekalongan. Agar dapat diketahui pengaruh variabel bebas terhadap variabel terikat tersebut baik secara parsial maupun secara simultan perlu dilakukan penelitian dengan menggunakan penelitian survey menggunakan pendekatan kuantitatif. Populasi dalam penelitian ini adalah dokter se-karisidenan Pekalongan yang menjadi pelanggan atau meresepkan obat dari PT. Hexpharmjaya. Data penelitian akan dikumpulkan dengan teknik wawancara dan kuesioner. Analisis data untuk menguji hipotesis yang digunakan adalah analisis regresi berganda, pengujian hipotesis, dan analisis koefisien determinasi. Hasil penelitian membuktikan bahwa terdapat pengaruh yang signifikan penurunan harga obat pelayanan dan citra perusahaan pada PT. Hexpharmjaya terhadap kepuasan konsumen Se-Karisidenan Pekalongan dan tidak terdapat pengaruh yang signifikan distribusi obat pada PT. Hexpharmjaya terhadap Kepuasan konsumen Se-Karisidenan Pekalongan.
\end{abstract}

Kata Kunci: Penurunan Harga; Pelayanan; Citra Perusahaan; Distribusi Obat ; Kepuasan 



\section{PENDAHULUAN}

Pelayanan farmasi adalah bagian yang tidak terpisahkan dari sistem pelayanan kesehatan yang berorientasi kepada pelayanan pasien dan penyediaan obat yang bermutu. Obat merupakan komponen yang penting dalam upaya pelayanan kesehatan, baik di pusat pelayanan kesehatan primer maupun di tingkat pelayanan yang lebih tinggi. Penyediaan obat sesuai dengan tujuan pembangunan kesehatan yaitu menjamin tersedianya obat dengan mutu terjamin dan tersedia merata dan teratur sehingga mudah diperoleh pada waktu dan tempat yang tepat (Kuingu, 2014).

Tjiptono (2008) menyatakan bahwa harga merupakan salah satu elemen bauran pemasaran yang paling fleksibel yang dapat dengan cepat berubah, setelah mengubah karakteristik produk tertentu dan layanan. Keputusan untuk harga paling efektif bila diselaraskan dengan unsur-unsur bauran pemasaran lain (produk atau jasa, tempat dan promosi).

Konsumen dalam penelitian ini adalah dokter 1) dokter dispensing, yaitu dokter yang menyediakan obat di tempat praktek, 2) dokter yang mempunyai surat ijin menyimpan obat (SIMO) dikarenakan lokasi dokter yang jauh dari aptotik atau berada di pinggiran kota, maka dokter tersebut berhak menyimpan obat di tempat prakteknya setelah sebelumnya mengajukan SIMO di Dinas Kesehatan (DINKES) dimana dokter berdomisili dan 3) dokter yang memiliki apotik.

Pembinaan dan pengembangan karyawan baru ataupun lama dalam organisasi adalah salah satu kegiatan dalam rangka menyesuaikan diri dengan perubahan dan perkembangan karyawan. Oleh sebab itu, perlu dilakukan penilaian atas pekerjaan yang telah dilaksanakan oleh karyawan atau disebut dengan penilaian kinerja. Kinerja merupakan tingkat pencapaian kerja individu (pegawai) setelah berusaha atau bekerja keras atau hasil akhir dari suatu aktivitas (Silalahi, 2013:408).

Penelitian yang dilakukan oleh Ajji (2014) dengan variabel kualitas pelayanan, harga dan fasilitas serta kepuasan pasien. Dengan menggunakan analisis regresi berganda. Hasil penelitian menujukkan bahwa kualitas pelayanan, harga dan fasilitas berpengaruh terhadap kepuasan pasien. Hasil penelitian Ajji (2014) ini bertentangan dengan hasil penelitian yang dilakukan oleh Atmaja (2011) yang membuktikan bahwa kewajaran harga tidak berpengaruh terhadap kepuasan pelanggan.

Kinerja karyawan dipengaruhi oleh bermacam-macam ciri pribadi dari masingmasing individu. Dalam perkembangan yang kompetitif dan mengglobal, perusahaan membutuhkan karyawan yang berprestasi tinggi. Pada saat yang sama, karyawan memerlukan umpan balik atas kinerja mereka sebagai pedoman bagi tindakan-tindakan mereka pada masa yang akan datang, oleh karena itu, penilaian seharusnya menggambarkan kinerja karyawan (Rivai dan Sagala, 2013:547).

Berdasarkan uraian latar belakang di atas, maka perlu dilakukan penelitian kembali mengenai faktor yang mempengaruhi kepuasan konsumen. Oleh karena itu dilakukan penelitian dengan judul "Pengaruh Penurunan Harga Obat, Pelayanan, Citra Perusahaan Dan Distribusi Obat Pada PT. Hexpharmjaya Terhadap Kepuasan konsumenSe Karisidenan Pekalongan".

\section{TINJAUAN PUSTAKA Pemasaran}

Sebagai ilmu sekaligus seni, pemasaran (marketing) mengalami perkembangan pesat dan dramatis. Berbagai trasnformasi telah, sedang, dan akan terus berlangsung. Peranan dan arti penting pemasaran semakin diakui dan disadari oleh para pelaku bisnis. McKenna (1991) bahkan menegasakan bahwa "marketing is everything and everything is marketing". Dengan kata lain, pemasaran bukan lagi sekedar departemen atau fungsi manajerial dalam sebuah 
organisasi. Pemasaran telah menjelma menjadi filsofi dan cara berbisnis yang berorientasi pada pemuasan kebutuhan dan keinginan pelanggan secara efektif, efisien, dan etis sedemikian rupa sehingga lebih unggul dibandingkan para pesaing dan berkontribusi pada peningkatan kesejahteraan masyarakat dan lingkungan secara umum (Tjiptono dan Chandra, 2012: 21).

Dalam rangka merespon perubahan-perubahan lingkungan pemasaran, kini banyak bermunculan ancangan baru dalam pemasaran yang beberapa di antaranya adalah (Tjiptono dan Chandra, 2012: 22) :

1. Relationship Marketing (RM)

Yaitu peralihan dari fokus pada transaksi tunggal menjadi upaya membangun relasi dengan pelanggan yang menguntungkan dalam jangka panjang.

2. Customer Lifetime Value (CLV)

Yaitu peralihan fokus dari laba per transaksi penjualan menjadi laba berdasarkan manajemen nilai pelanggan seumur hidup. CLV bisa didefinisikan sebagai "net present value of future profit from a customer" (Kumar, 2008). Sejumlah perusahaan menawarkan produk secara reguler dengan harga murah per unitnya, dikarenakan mereka lebih mengutamakan bisnis dalam jangka panjang dari setiap pelanggannya.

3. Customer Share

Yaitu peralihan dari fokus pada pangsa pasar (market share) menjadi pangsa pelanggan. Upaya menciptakan pangsa pelanggan ini bisa dilakukan dengan jalan menawarkan berbagai variasi produk kepada pelanggan saat ini.

4. Customers as co-creators of value

Yakni memandang pelanggan sebagai co-produser dalam proses penciptaan nilai tambah. Perspektif ini bukan hanya terbatas pada koteks jasa yang menekankan proses berkesinambungan dan interaksi aktif antara penyedia jasa dan konsumen. Akan tetapi, pandangan ini juga relevan bagi konteks produk manufaktur.

5. Target Marketing

Yaitu peralihan dari upaya menjual kepada setiap orang menjadi usaha untuk menjadi perusahaan terbaik yang melayani pasar sasaran (target market) yang dirumuskan secara spesifik. Target marketing difasilitasi dengan pesatnya perkembangan special-interest magazines, TV channels, internet news groups, dan social media.

\section{Harga}

Schifmann dan kanuk (2008 : 31) menyebutkan bahwa persepsi adalah cara orang memandang dunia ini. Dari definisi yang umum dapat dilihat bahwa persepsi seseorang akan berbeda satu orang dengan yang lain. Cara memandang dunia sudah pasti dipengaruhi oleh sesuatu dari dalam maupun luar orang itu. Kotler (2007 : 213) mendefinisikan persepsi sebagai proses dimana sensasi yang diterima oleh seseorang dipilah dan dipilih, kemudian diatur dan diinterprestasikan.

Menurut Tjiptono (2008 : 95), secara sederhana istilah harga dapat diartikan sebagai jumlah uang (satuan moneter) dan atau aspek lain (non moneter) yang mengandung utilitas / keunggulan tertentu yang diperlukan untuk mendapatkan suatu jasa. Utilitas merupakan atribut atau faktor yang berpotensi memuaskan kebutuhan dan keinginan tertentu.

Menurut Chandra (2006 : 69) bahwa harga merupakan pernyataan nilai dari suatu produk (a statement of value). Harga adalah apa yang dibayar seseorang untuk apa yang diperolehnya dan nilainya dinyatakan dalam nilai mata uang.

Menurut Tjiptono (2008:152) Pada dasarnya ada empat jenis tujuan penetapan harga yaitu : 
1. Tujuan berorientasi pada laba

Asumsi teori ekonomi klasik menyatakan bahwa setiap perusahaan selalu memilih harga yang dapat menghasilkan laba paling tinggi. Tujuan ini dikenal dengan istilah maksimalisasi laba. Dalam era persaingan global yang kondisinya sangat kompleks dan banyak variabel yang berpengaruh terhadap daya saing setiap perusahaan, maksimalisasi laba sangat sulit dicapai, karena sangat sulit untuk memperkirakan secara akurat jumah penjualan yang dapat dicapai pada tingkat harga tertentu. Dengan demikian tidak mungkin suatu perusahaan dapat mengetahui secara pasti tingkat harga yang dapat menghasilkan laba maksimum.

2. Tujuan berorientasi pada volume

Selain tujuan penetapan harga berorientasi laba, ada pula perusahaan yang menetapkan harga berdasarkan tujuan yang berorientasi pada volume tertentu atau yang biasa dikenal dengan volume pricing objective.

3. Tujuan berorientasi pada citra

Citra suatu perusahaan dapat dibentuk melalui strategi penetapan harga. Perusahaan dapat menetapkan harga tinggi untuk membentuk atau mempertahankan citra prestisius, sementara itu harga rendah dapat digunakan untuk membentuk citra nilai tertentu. Citra (image) suatu perusahaan dapat dibentuk melalui strategi penetapan harga. Perusahaan dapat menetapkan harga tinggi untuk membentuk atau mempertahankan citra prestisius. Sementara itu harga rendah dapat digunakan untuk membentuk citra nilai tertentu (image of value).

4. Tujuan stabilisasi harga

Tujuan stabilisaisi harga dilakukan dengan jalan menetapkan harga untuk mempertahankan hubungan yang stabil antara harga suatu perusahaan dan harga pemimpin industri. Dalam pasar yang konsumennya sangat sensitif terhadap harga, bila suatu perusahaan menurunkan harganya, maka para pesaingnya harus menurunkan pula harga mereka.

5. Tujuan - tujuan lainnya

Harga dapat pula ditetapkan dengan tujuan mencegah masuknya pesaing, mempertahankan loyalitas konsumen, mendukung ulang, atau menghindari campur tangan pemerintah

\section{Pelayanan}

Pengertian atau definisi kualitas dapat berbeda makna bagi setiap orang, karena kualitas memiliki banyak kriteria dan sangat tergantung pada konteksnya. Banyak pakar dibidang kualitas yang mencoba untuk mendefinisikan kualitas berdasarkan sudut pandangnya masing-masing. Beberapa diantaranya yang paling populer adalah yang dikembangkan oleh tiga pakar kualitas tingkat internasional, yaitu mengacu pada pendapat W. Edwards Deming, Philip B. Crosby dan Joseph M. Juran (Purnama, 2006 : 10).

Crosby, membuat definisi kualitas yang lebih luas cakupannya, yaitu kualitas merupakan kesesuaian dengan persyaratan. Deming mendefinisikan kualitas sebagai derajat keseragaman produk yang bisa diprediksi dan tergantung pada biaya rendah dan pasar. Sedangkan Juran mendefinisikan kualitas sebagai kesesuaian dengan penggunaan atau memuaskan kebutuhan konsumen (Purnama, 2006 : 10).

Menurut Tjiptono (2008:51), terdapat 5 macam perspektif kualitas, yaitu:

1. Transcendental approach

Kualitas dipandang sebagai innate execellence, di mana kualitas dapat dirasakan atau diketahui, tetapi sulit didefinisikan dan dioperasionalisasikan, biasanya diterapkan dalam dunia seni. 


\section{Product-based approach}

Kualitas merupakan karakteristik atau atribut yang dapat dikuantitatifkan dan dapat diukur. Perbedaan dalam kualitas mencerminkan perbedaan dalam jumlah beberapa unsur atau atribut yang dimiliki produk.

3. User-based approach

Kualitas tergantung pada orang yang memandangnya, sehingga produk yang memuaskan preferensi seseorang (perceived quality) merupakan produk yang berkualitas tinggi.

4. Manufacturing-based approach

Kualitas sebagai kesesuaian / sama dengan persyaratan. Dalam sektor jasa bahwa kualitas seringkali didorong oleh tujuan peningkatan produktivitas dan penekanan biaya.

5. Value-based approach

Kualitas dipandang dari segi nilai dan harga. Kualitas dalam pengertian ini bersifat relatif, sehingga produk yang memiliki kualitas paling tinggi belum tentu produk yang paling bernilai. Akan tetapi yang paling bernilai adalah barang atau jasa yang paling tepat dibeli.

\section{Citra Perusahaan}

Keinginan sebuah organisasi untuk mempunyai citra yang baik pada publik sasaran berawal dari pengertian yang tepat mengenai citra stimulus adanya pengelolaan upaya yang perlu dilaksanakan. Ketepatan pengertian citra agar organisasi dapat menetapkan upaya dalam mewujudkannya pada obyek dan mendorong prioritas pelaksanaan.

Sutisna (2011) menyatakan bahwa citra adalah total persepsi terhadap suatu obyek yang dibentuk dengan memproses informasi dari berbagai sumber setiap waktu. Alma (2011) menyatakan bahwa citra didenifisikan sebagai kesan yang diperoleh sesuai dengan pengetahuan dan pengalaman seseorang tentang sesuatu. Menurut Davies et al. dalam Vera (2006) dikatakan bahwa citra diartikan sebagai pandangan mengenai perusahaan oleh para pemegang saham eksternal, khususnya oleh para pelanggan. Definisi citra menurut Renald Kasali dalam Iman (2010) yaitu kesan yang timbul karena pemahaman akan suatu kenyataan.

Pentingnya citra perusahaan dikemukakan Sutisna (2011) sebagai berikut.

1. Menceritakan harapan bersama kampanye pemasaran eksternal. Citra positif memberikan kemudahan perusahaan untuk berkomunikasi dan mecapai tujuan secara efektif sedangkan citra negatif sebaliknya.

2. Sebagai penyaring yang mempengaruhipersepsi pada kegiatan perusahaan. Citra positif menjadi pelindung terhadap kesalahan kecil. Kualitas teknis atau fungsional sedangkan citra negatif dapat memperbesar kesalahan tersebut.

3. Sebagai fungsi dari pengalaman dan harapan konsumen atas kualitas pelayanan perusahaan.

4. Mempunyai pengaruh penting terhadap manajemen atau dampak internal. Citra perusahaan yang kurang jelas dan nyata mempengaruhi sikap karyawan terhadap perusahaan.

Harrison dalam Iman (2010) mengungkapkan bahwa informasi yang lengkap mengenai citra perusahaan meliputi empat elemen sebagai berikut:

1. Personality, keseluruhan karakteristik perusahaan yang dipahami publik sasaran seperti perusahaan yang dapat dipercaya, perusahaan yang mempunyai tanggung jawab sosial.

2. Reputation, hal yang telah dilakukan perusahaan dan diyakini publik sasaran berdasarkan pengalaman sendiri maupun pihak lain seperti kinerja keamanan transaksi sebuah bank.

3. Value, Nilai-nilai yang dimiliki suatu perusahaan dengan kata lain budaya perusahaan seperti sikap manajemen yang peduli terhadap pelanggan, karyawan yang cepat tanggap terhadap permintaan maupun keluhan pelanggan. 
4. Corporate Identity, komponen-komponen yang mempermudah pengenalan publik sasaran terhadap perusahaan seperti logo, warna dan slogan.

\section{Distribusi Obat}

Distribusi merupakan kegiatan yang harus dilakukan oleh pengusaha untuk menyalurkan, menyebarkan, mengirimkan serta menyampaikan barang yang dipasarkannnya itu kepada konsumen. Saluran distribusi (saluran pemasaran) dapat dilihat sebagai kumpulan organisasi independen yang terlibat dalam proses membuat suatu produk atau jasa tersedia untuk digunakan atau dikonsumsi (Kotler, 2007: 683).

Berdasarkan definisi di atas diketahui beberapa unsur penting yaitu:

1. Saluran melaksanakan dua kegiatan penting untuk mencapai tujuan yang mengadakan penggolongan produk dan mendistribusikannya. Penggolongan produk menunjukkan jumlah dari berbagai keperluan produk yang dapat memberikan kepuasan kepada pasar. Jadi, barang merupakan bagian dari penggolongan produk dan masing-masing produk mempunyai satu tingkat harga tertentu.

2. Tujuan dari saluran distribusi adalah untuk mencapai pasar-pasar tertentu, jadi pasar merupakan tujuan akhir dari kegiatan saluran.

Berdasarkan definisi di atas diketahui saluran distribusi dari suatu perusahaan terdiri dari:

1. Saluran langsung

Saluran langsung yaitu dimana produsen melakukan transaksi langsung dengan pelangan. Adapun Keuntungan dari saluran distribusi langsung dapat dilihat dari perbedaan yang jelas antara biaya produksi dan harga yang dibayar oleh pelanggan kepada produsen. Produsen dapat dengan mudah memperoleh atas masukan produk secara langsung.

2. Saluran satu tingkat adalah peran cara berada diantara produsen dan konsumen. Pedagang adalah perantara pemasaran yang menjadi milik produk dan kemudian menjualnya kembali. Agen adalah perantara pemasaran yang mempertemukan pembeli dan penjual produk tanpa harus menjadi pemilik produk.

3. Saluran dua tingkat adalah dua perantara pemasaran berada di antara produsen dan konsumen.

\section{Kepuasan}

Kepuasan konsumen adalah suatu ukuran yang merefleksikan antara struktur, proses, dan hasil akhir pelayanan. Kepuasan konsumen dipandang sebagai konsep multi dimensional yang mellibatkan biaya, interpersonal serta hasil akhir. Kepuasan juga dapat dipertimbangkan sebagai hubungan antara harapan dan pengalaman dimana semakin dekat dengan harapan akan semakin puas konsumen (Assegaff, 2009: 174).

Menurut Tjiptono (2008: 213), di tengah beragamnya cara mengukur kepuasan pelanggan, terdapat kesamaan paling tidak dalam enam konsep inti mengenai objek pengukuran sebagai berikut:

1. Kepuasan Pelanggan Keseluruhan (Overall Customer Satisfaction)

Pertama, mengukur tingkat kepuasan pelanggan terhadap produk dan/atau jasa perusahaan bersangkutan. Kedua, menilai dan membandingkannya dengan tingkat kepuasan keseluruhan terhadap produk dan/atau jasa pesaing.

2. Dimensi Kepuasan Pelangga

Pertama, mengidentifikasi dimensi-dimensi kunci kepuasan pelanggan. Kedua, meminta pelanggan menilai produk dan/atau jasa perusahaan berdasarkan item-item spesifik, seperti kecepatan layanan, fasilitas layanan, atau keramahan staf layanan pelanggan. Ketiga, meminta pelanggan menilai produk dan/atau jasa pesaing berdasarkan item-item spesifik yang sama. Dan keempat, meminta para 
pelanggan untuk menetukan dimensi-dimensi yang menurut mereka paling penting dalam menilai kepuasan pelanggan keseluruhan.

3. Konfirmasi Harapan (Confirmation of Expectation)

Dalam konsep ini, kepuasan tidak diukur langsung, tetapi disimpulkan berdasarkan kesesuaian/ketidaksesuaian antara harapan pelanggan dengan kinerja aktual produk perusahaan pada sejumlah atribut atau dimensi penting.

4. Minat Pembelian Ulang (Repurchase Intent)

Kepuasan pelanggan diukur secara behavioral dengan cara menanyakan apakah pelanggan akan berbelanja atau menggunakan jasa perusahaan lagi.

5. Kesediaan untuk Merekomendasi (Willingness to Recommend)

Dalam kasus produk yang pembelian ulangnya relatif lama atau bahkan hanya terjadi satu kali pembelian (seperti pembelian mobil, broker rumah, asuransi jiwa, tur keliling dunia, dan sebagainya), kesediaan pelanggan untuk merekomendasikan produk kepada teman atau keluarganya menjadi ukuran yang penting untuk dianalisis dan ditindaklanjuti.

6. Ketidakpuasan Pelanggan (Customer Dissatisfaction)

Beberapa macam aspek yang sering ditelaah guna mengetahui ketidakpuasan pelanggan, meliputi komplain, retur atau pengembalian produk, biaya garansi, product recall (penarikan kembali produk dari pasar), gethok tular negatif, dan defections (konsumen yang beralih ke pesaing).

\section{Kerangka Konseptual}

Kerangka pemikiran dalam penelitian ini adalah berdasarkan atas fakta adanya penurunan penjualan PT. Hexpharm Jaya wilayah se-Karisidenan Pekalongan. Persaingan harga yang semakin ketat dengan perusahaan farmasi yang lain, membuat PT. Hexpharm Jaya berusaha mempertimbangkan kembali kebijakan harga yang ditawarkan sehingga menimbulkan persepsi penurunan harga dan menimbulkan kepuasan pada dokter sebagai pelanggan. Tidak hanya harga yang dipertimbangkan tetapi juga persepsi pelanggan mengenai kualitas pelayanan, citra perusahaan dan distribusi obat yang juga akan dihubungkan dengan kepuasan pelanggan. Dengan demikian kerangka berpikir dalam penelitian ini digambarkan sebagai berikut:

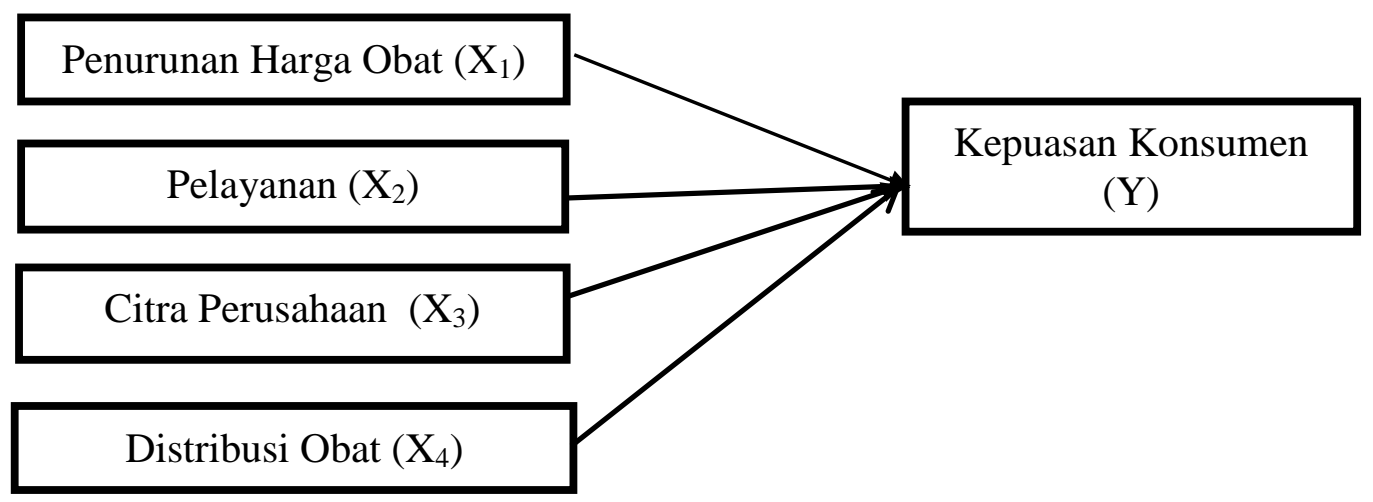

Gambar 1. Kerangka Berpikir Penelitian 


\section{Hipotesis}

$\mathrm{H}_{1}$ : Terdapat pengaruh penurunan harga obat pada PT. Hexpharmjaya terhadap Kepuasan konsumenSe-Karisidenan Pekalongan.

$\mathrm{H}_{2}$ : Terdapat pengaruh pelayanan pada PT. Hexpharmjaya terhadap Kepuasan konsumenSe-Karisidenan Pekalongan.

$\mathrm{H}_{3}$ : Terdapat pengaruh citra perusahaan PT. Hexpharmjaya terhadap kepuasan Konsumen Se-Karisidenan Pekalongan.

$\mathrm{H}_{4}$ : Terdapat pengaruh distribusi obat pada PT. Hexpharmjaya terhadap kepuasan Konsumen Se-Karisidenan Pekalongan.

\section{METODE PENELITIAN}

\section{Variabel Penelitian}

Variabel dependen pada penelitian ini adalah kepuasan. Kepuasan adalah perasaan senang atau kecewa seseorang yang muncul setelah membandingkan antara kinerja (hasil) produk yang dipikirkan terhadap kinerja yang diharapkan. Indikator dari kepuasan adalah :

1. Keandalan pelayanan

2. Citra positif

3. Perlakuan

Variabel penelitian terdiri dari variabel independen yaitu :

1. Penurunan Harga $\left(\mathrm{X}_{1}\right)$

Harga adalah sejumlah nilai yang ditukarkan konsumen dengan manfaat memiliki atau menggunakan produk atau jasa yang lainnya ditetapkan oleh pembeli atau penjual untuk suatu harga yang sama terhadap semua pembeli. Indikator dari harga adalah:

b. Diskon adalah potongan harga yang diberikan oleh oleh penjual kepada pembeli sebagai peghargaan atas aktivitas tertentu dari pembeli yang menyenangkan bagi penjual.

c. Penyesuaian harga adalah penetapan harga yang menyesuaikan harga dasar untuk memperhitungkan perbedaan dan perubahan situasi.

d. Penyesuaian geografis adalah penyesuaian terhadap harga yang dilakukan oleh produsen sehubungan dengan biaya transportasi produk dari penjual kepada pembeli.

2. Pelayanan $\left(\mathrm{X}_{2}\right)$

Pelayanan adalah suatu kegiatan atau urutan kegiatan yang terjadi dalam interaksi langsung antara seseorang dengan orang lain atau mesin secara fisik, dan menyediakan kepuasan pelanggan. Indikator dari pelayanan adalah :

a. Keandalan adalah kemampuan perusahaan untuk memberikan pelayanan sesuai dengan yang dijanjikan secara akurat dan terpercaya

b. Daya tanggap adalah keinginan para staf untuk membantu para konsumen dan memberikan pelayanan dengan tanggap

c. Jaminan adalah pengetahuan, kesopan santunan dan kemampuan para pegawai perusahaan untuk menumbuhkan rasa percaya para pelanggan kepada perusahaan.

d. Empati adalah memberikan perhatian yang tulus dan bersifat individual atau pribadi yang diberikan kepada para pelanggan dengan berupaya memahami keinginan konsumen

3. Citra Perusahaan $\left(\mathrm{X}_{3}\right)$

Citra perusahaan adalah kesan yang diperoleh sesuai dengan pengetahuan dan pengalaman seseorang tentang sesuatu. Indikator dari citra perusahaan adalah :

a. Advertising adalah keseluruhan proses yang meliputi penyiapan, perencanaan, pelaksanaan dan pengawasan penyampaian iklan. 
b. Public relation adalah usaha yang direncanakan secara terus-menerus dengan sengaja, guna membangun dan mempertahankan pengertian timbal balik antara organisasi dan masyarakatnya.

c. Physical image adalah bukti fisik yang dapat memberikan citra diri bagi perusahaan di mata konsumennya

d. Actual experience adalah pengalaman yang langsung dirasakan oleh pelanggan dalam mengkonsumsi barang dan jasa.

4. Distribusi $\left(\mathrm{X}_{4}\right)$

Distribusi adalah kegiatan yang harus dilakukan oleh perusahaan untuk menyalurkan, menyebarkan, mengirimkan serta menyampaikan barang yang dipasarkannnya itu kepada konsumen. Saluran distribusi (saluran pemasaran) dapat dilihat sebagai kumpulan organisasi independen yang terlibat dalam proses membuat suatu produk atau jasa tersedia untuk digunakan atau dikonsumsi. Indikator dari distribusi adalah:

a. Pertimbangan pasar adalah faktor penentu yang mempengaruhi pemilihan saluran distribusi oleh manajemen sehubungan dengan pasar yang dituju

b. Pertimbangan produk adalah pertimbangan perusahaan sehubungan dengan produk yang dijual.

c. Pertimbangan perantara adalah pertimbangan perusahaan dalam menggunakan perantara untuk memasarkan produknya.

\section{Populasi dan Sampel}

Populasi dan sampel yang diamati adalah dokter se-karsidenan Pekalongan yang merupakan dokter dispensing yaitu dokter yang menyediakan obat di tempat praktek.

Teknik penentuan Sampel dalam penelitian ini menggunakan teknik sampling purposive adalah teknik penentuan sampel dengan pertimbangan tertentu (Sugiyono, 2010:62). Jumlah sampel penelitian ini berjumlah 125 orang dokter yang akan menjadi responden dalam penelitian ini.

\section{Jenis Data dan Sumber Data}

Dalam penelitian ini digunakan dua jenis data yaitu data primer dan data sekunder. Data primer yaitu data yang berasal langsung dari sumber data yang dikumpulkan secara khusus dan berhubungan langsung dengan permasalahan yang diteliti. Data primer biasanya dikumpulkan melalui wawancara dan kuesioner (Ferdinand, 2011).

\section{Teknik Pengumpulan Data}

Teknik pengumpulan data yang digunakan adalah wawancara, kuesioner atau Angket merupakan Data yang diperoleh secara langsung dari pihak yang berwenang dengan mengajukan pertanyaan yang sistematis dan atau tanpa bantuan daftar pertanyaan (Moleong, 2010).

\section{Alat Analisis}

Penelitian ini menggunakan analisis regresi linier berganda yang bertujuan untuk mengetahui hubungan fungsional antara variabel independen secara bersama-sama terhadap variabel dependen. Rumus yang digunakan adalah (Sugiyono, 2010: 87):

$$
Y^{\wedge}=\mathrm{a}+\mathrm{b}_{1} \mathrm{X}_{1}+\mathrm{b}_{2} \mathrm{X}_{2}+\mathrm{b}_{3} \mathrm{X}_{3}+\mathrm{b}_{4} \mathrm{X}_{4}+\mathrm{e}
$$

Keterangan :

$$
\begin{array}{ll}
Y^{\wedge} & =\text { Kepuasan konsumen } \\
\mathrm{a} & =\text { Konstanta } \\
\mathrm{b}_{1}, \mathrm{~b}_{2}, \mathrm{~b}_{3} \mathrm{~b}_{4} & =\text { Koefisien regresi } \\
\mathrm{X}_{1} & =\text { Penurunan harga obat. }
\end{array}
$$




$$
\begin{array}{ll}
\mathrm{X}_{2} & =\text { Pelayanan. } \\
\mathrm{X}_{3} & =\text { Citra perusahaan } \\
\mathrm{X}_{4} & =\text { Distribusi Obat }
\end{array}
$$

\section{HASIL DAN PEMBAHASAN Analisis Regresi Berganda}

\begin{tabular}{|c|c|c|c|c|c|c|}
\hline \multirow{2}{*}{\multicolumn{2}{|c|}{ Model }} & \multicolumn{2}{|c|}{$\begin{array}{l}\text { Unstandardized } \\
\text { Coefficients }\end{array}$} & \multirow{2}{*}{$\begin{array}{c}\text { Standardized } \\
\text { Coefficients } \\
\text { Beta }\end{array}$} & \multirow[b]{2}{*}{$t$} & \multirow[b]{2}{*}{ Sig. } \\
\hline & & B & Std. Error & & & \\
\hline \multirow[t]{5}{*}{1} & (Constant) & 1,806 & ,871 & & 2,074 &, 040 \\
\hline & PenurunanHarga_X1 & ,488 & ,060 &, 583 & 8,140 & , 000 \\
\hline & Pelayanan_X2 & , 151 & ,062 & , 142 & 2,456 & ,015 \\
\hline & CitraPerusahaan_X3 & , 145 & ,049 & , 197 & 2,982 & ,003 \\
\hline & Distribusi_X4 & ,052 & ,057 & ,059 & ,923 & ,358 \\
\hline
\end{tabular}

Tabel 1. Hasil Analisis Regresi Berganda

Coefficie nts ${ }^{\mathrm{a}}$

a. Dependent Variable: KepuasanDokter_Y

Berdasarkan hasil perhitungan analisis regresi ganda dengan menggunakan program SPSS diperoleh persamaan regresi yaitu:

$\hat{Y}=1,806+0,488 X_{1}+0,151 X_{2}+0,145 X_{3}+0,052 X_{4}$.

Persamaan regresi berganda di atas dapat diambil suatu analisis bahwa:

a. Konstanta sebesar 1,806 artinya jika tidak ada variabel penurunan harga obat, pelayanan, citra perusahaan dan distribusi maka Kepuasan konsumen adalah tetap.

b. Koefisien regresi untuk variabel penurunan harga obat sebesar 0,488 artinya jika variabel penurunan harga obat ditingkatkan sedangkan variabel lain tetap, maka akan menyebabkan peningkatan Konsumen konsumen.

c. Koefisien regresi untuk variabel pelayanan sebesar 0,151 artinya jika variabel pelayanan ditingkatkan sedangkan variabel lain tetap, maka akan menyebabkan peningkatan Konsumen konsumen.

d. Koefisien regresi untuk citra perusahaan sebesar 0,145 artinya jika variabel citra perusahaan ditingkatkan sedangkan variabel lain tetap, maka akan menyebabkan peningkatan Konsumen konsumen.

e. Koefisien regresi untuk distribusi obat sebesar 0,052 artinya jika variabel distribusi obat ditingkatkan sedangkan variabel lain tetap, maka akan menyebabkan peningkatan Konsumen konsumen.

\section{Uji Hipotesis Secara Simultan (Uji Kesesuaian Model)}

Tabel 2. Hasil Uji Hipotesis Secara Simultan

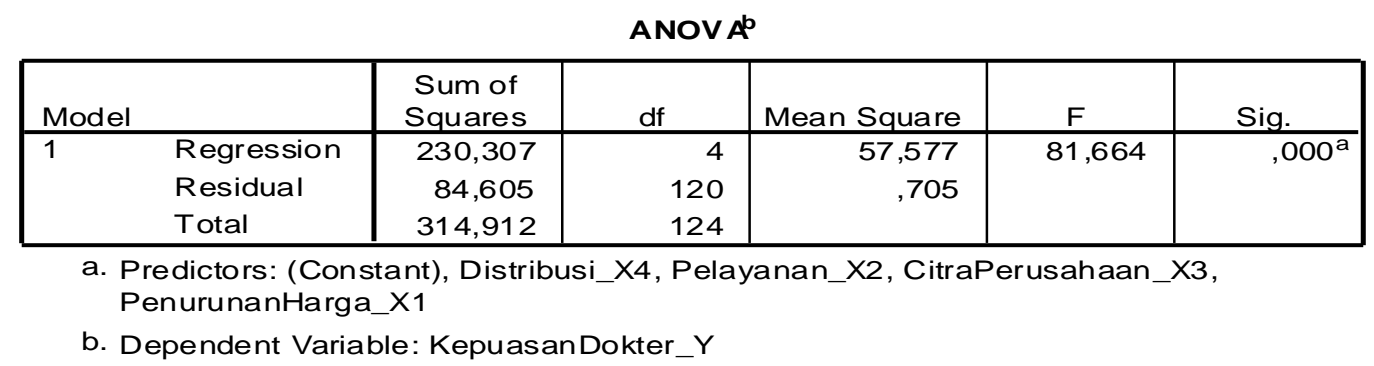

Berdasarkan hasil uji $\mathrm{F}$ pada tabel di atas diperoleh hasil nilai signifikansi sebesar $0,000<0,05$ dapat dikatakan bahwa model regresi yang digunakan dalam penelitian ini sudah tepat, artinya semua variabel independennya yaitu variabel penurunan harga obat, 
pelayanan, citra perusahaan, dan distribusi obat secara simultan merupakan penjelas yang signifikan terhadap variabel dependen.

\section{Analisis Koefisien Determinasi}

\section{Tabel 3. Hasil Uji Koeefisien Determinasi}

\begin{tabular}{|l|r|r|r|r|}
\multicolumn{7}{|c|}{ Model Summary } \\
\hline Model & $\mathrm{R}$ & R Square & $\begin{array}{c}\text { Adjusted } \\
\text { R Square }\end{array}$ & $\begin{array}{c}\text { Std. Error of } \\
\text { the Estimate }\end{array}$ \\
\hline 1 &, $855^{\mathrm{a}}$ &, 731 &, 722 &, 840 \\
\hline
\end{tabular}

Dari tabel 3 dapat diketahui bahwa besarnya nilai koefisien determinasi atau R2 sebesar 0,731 atau 73,1 \%. Dengan demikian dapat diartikan bahwa 73,1 \% variabel Kepuasan konsumen pada model dapat diterangkan oleh penurunan harga obat, pelayanan, citra perusahaan dan distribusi obat sedangkan sisanya yaitu 26,9 persen $(100 \%-73,1 \%)$ dipengaruhi oleh variabel lain diluar model.

\section{Pembahasan}

Hasil analisis data tersebut akan menjelaskan hubungan kausalitas antara variabel yang sedang dikembangkan dalam model penelitian ini. Setelah dilakukan penelitian terhadap empat hipotesis yang diujikan, berikut ini adalah pembahasan dari penelitian ini:

Terdapat pengaruh positif dan signifikan antara penurunan harga obat pada PT. Hexpharmjaya terhadap Kepuasan konsumen Se-Karisidenan Pekalongan.Menurut Consuegra et al. (2007) terdapat hubungan antara harga dan kepuasan pelanggan. Penilaian dari kewajaran harga kemungkinan besar didasarkan pada perbandingan transaksi yang melibatkan berbagai pihak. Ketika dirasakan terjadi perbedaan harga, maka tingkat kesamaan antara transaksi merupakan unsur penting dari penilaian kewajaran harga. Kewajaran harga yang dirasakan akan menimbulkan kepuasan pada pelanggan. Hal tersebut sesuai dengan teori atau pendapat dari Tjiptono (2008) yang menyatakan bahwa harga merupakan salah satu elemen bauran pemasaran yang paling fleksibel yang dapat dengan cepat berubah, setelah mengubah karakteristik produk tertentu dan layanan. Keputusan untuk harga paling efektif bila diselaraskan dengan unsur-unsur bauran pemasaran lain (produk atau jasa, tempat dan promosi). Hasil penelitian ini konsisten dengan hasil penelitian yang dilakukan oleh Utami (2014), Widyaswati (2010), dan Sriwijayanti (2008) membuktikan bahwa kewajaran harga berpengaruh secara signifikan terhadap kepuasan konsumen.

Terdapat pengaruh positif dan signifikan antara pelayanan pada PT. Hexpharmjaya terhadap Kepuasan konsumen Se-Karisidenan Pekalongan. Menurut Parasuraman (2006) kepuasan seorang konsumen ditentukan oleh beberapa faktor, salah satunya pelayanan yang diberikan kepada konsumen tersebut. Kualitas pelayanan yang tinggi yang diberikan oleh perusahaan akan membuat pelanggan puas terhadap produk atau jasa yang perusahaan sampaikan. Kotler (2007) mengatakan bahwa kualitas pelayanan baik jasa atau produk dan kepuasan merupakan dua konsep inti dalam praktek pemasaran. Seperti yang dikemukakan oleh Day (2000) yang mengatakan bahwa bagaimanapun juga pondasi dari konsep pemasaran adalah pemenuhan kepuasan pelanggan. Seorang konsumen merasa puas jika pelyanan yang diberikan oleh perusahaan sesuai dengan harapan. Hasil penelitian ini konsisten dengan hasil penelitian yang dilakukan oleh Utami (2014), Gultom (2014), dan Widyaswati (2010) membuktikan bahwa kualitas pelayanan berpengaruh secara signifikan terhadap kepuasan konsumen. 
Terdapat pengaruh positif dan signifikan antara citra perusahaan pada PT. Hexpharmjaya terhadap Kepuasan konsumen Se-Karisidenan Pekalongan. Citra perusahaan dapat menjadi informasi ekstrinsik petunjuk bagi pembeli baik yang ada dan potensi dan mungkin atau tidak dapat mempengaruhi loyalitas pelanggan (misalnya kesediaan untuk memberikan kata positif dari mulut ke mulut). Andreassen et al. (1997) menyatakan bahwa citra perusahaan diasumsikan berdampak akibat pada pilihan pelanggan perusahaan ketika atribut pelayanan sulit untuk dievaluasi, maka citra perusahaan didirikan dan dikembangkan di benak konsumen melalui komunikasi dan pengalaman. Citra perusahaan yang diyakini untuk menciptakan efek halo pada penilaian kepuasan pelanggan. Kepuasan / ketidakpuasan pelanggan membutuhkan pengalaman dengan layanan ini, dan dipengaruhi oleh kualitas yang dirasakan dan nilai layanan. Hal Itu adalah pendorong utama perilaku konsumen. Berdasarkan transaksi tersebut didorong sifat pengalaman kepuasan, beberapa penulis menyatakan bahwa citra perusahaan adalah fungsi pengaruh kumulatif dari kepuasan pelanggan. Hasil penelitian ini konsisten dengan hasil penelitian Cohen et al. yang menyebutkan bahwa kepuasan yang diikuti dengan citra perusahaan merupakan hal yang penting dalam sebuah konstruk. Sutanto (2009) dalam penelitiannya menemukan bahwa citra perusahaan mempunyai pengaruh yang positif terhadap kepuasan pelanggan.

Tidak terdapat pengaruh positif dan signifikan antara distribusi obat pada PT. Hexpharmjaya terhadap Kepuasan konsumen Se-Karisidenan Pekalongan. Menurut Listyarso (2005) distribusi suatu produk akan berpengaruh terhadap kinerja pemasaran yang akan mempengaruhi kepuasan konsumen. Hal tersebut sesuai dengan teori atau pendapat Kotler (2007) bahwa distribusi merupakan kegiatan yang harus dilakukan oleh pengusaha untuk menyalurkan, menyebarkan, mengirimkan serta menyampaikan barang yang dipasarkannnya itu kepada konsumen. Saluran distribusi (saluran pemasaran) dapat dilihat sebagai kumpulan organisasi independen yang terlibat dalam proses membuat suatu produk atau jasa tersedia untuk digunakan atau dikonsumsi. Saluran distribusi akan mempengaruhi kepuasan konsumen karena berkaitan dengan ketersediaan barang atau produk. Jika setiap kali konsumen membutuhkan barang atau jasa maka ketersediaan barang tersebut ada maka konsumen akan merasa puas. Semakin baik distribusi suatu produk atau jasa, maka semakin tinggi kepuasan konsumen. Sebaliknya semakin jelek distribusi suatu produk atau jasa, maka semakin rendah kepuasan konsumen. Hasil penelitian ini bertentangan dengan hasil penelitian yang dilakukan oleh Listyarso (2005) yang membuktikan bahwa distribusi memiliki pengaruh positif terhadap kinerja pemasaran.

\section{SIMPULAN}

Hasil penelitian membuktikan bahwa terdapat pengaruh positif dan signifikan antara penurunan harga obat, pelayanan, citra perusahaan terhadap kepuasan konsumen. Sementara, distribusi obat tidak berpengaruh positif dan signifikan terhadap kepuasan konsumen.

Saran yang bisa diberikan antara lain: pertamana, PT. Hexparm Jaya hendaknya meingkatkan pemberian diskon dan harga promo pada produk - produk obat tertentu dimaksudkan untuk lebih meningkatkan kepuasan konsumen. Kedua, Medical representatif PT. Hexparm Jaya hendaknya meningkatkan pelayanan kepada pelanggan dengan meningkatkan kemampuan berkomunikasi yang penuh keyakinan, mantap, dilandasi dengan sikap profesional yang jujur dan beretika, ditambah penguasaan product knowledge. Ketiga, meningkatkan kualitas periklanan baik melalui media elektronik dan media cetak maupun public relation untuk dapat meningkatkan citra perusahaan. Periklanan. PT. Hexparm Jaya harus mengutamakan konsep kualitas produk obat sehingga menanamkan rasa kepercayaan bagi para pelanggannya. 


\section{DAFTAR PUSTAKA}

Abednego. 2008. Analisis Pengaruh Saluran Pemasaran Dan Harga Terhadap Pendapatan Petani Jeruk Manis Di Daerah Sukanalu Kecamatan Barusjahe Kabupaten Karo. www.repository.usu.ac.id

Arikunto, Suharsimi. 2010. Prosedur Penelitian Pendekatan Praktek. Jakarta: Rineka Cipta. Assauri, Sofyan. 2014. Manajemen Pemasaran. Jakarta: PT Rajawali Pers

Assegaff, Mohammad. 2009. Pengaruh Kualitas Pelayanan Terhadap Kepuasan Pelanggan (Studi Pada Perusahaan Penerbangan PT. Garuda Di Kota Semarang). Jurnal Ekonomi dan Bisnis. 10(2). Semarang: Unissula.

Atmaja, Ni Puti Cempaka Dharmadewi. 2011. Pengaruh Kewajaran Harga, Citra Perusahaan Terhadap Kepuasan Dan Loyalitas Pengguna Jasa Penerbangan Domestik Garuda Indonesia Di Denpasar. Tesis Program Pascasarjana Universitas Udayana.

Buchari, Alma. 2011. Manajemen Pemasaran dan Pemasaran Jasa. Bandung: Alfabeta, Engel. 2005. Perilaku Konsumen. Jakarta: Binarupa Aksara.

Ferdinand, Augusty. 2011. Metode Penelitian Manajemen: Pedoman Penelitian untuk Skripsi, Tesis dan Disertasi Ilmu Manajemen. Semarang: Badan Penerbit Universitas Diponegoro.

Ghozali, Imam. 2011. Aplikasi Analisis Multivariate dengan Program IBM SPSS 19. Semarang: Badan Penerbit Universitas Diponegoro.

Gultom, Dedek K. 2014. Pengaruh Bauran Pemasaran Jasa dan kualitas Pelayanan Terhadap Kepuasan Mahasiswa Program Studi Manajemen Fakultas Ekonomi Universitas Muhammadiyah Sumatera Utara. Jurnal Manajemen \& Bisnis. 14(1)

Hermanto, Andy Wahyu. 2008. Analisa Tingkat Kepuasan Konsumen terhadap Pelayanan Terminal Peti Kemas Semarang. Tesis. Program Pascasarjana Universitas Diponegoro, Semarang

Kotler, Philip and Gary Amstrong. 2007. Dasar-Dasar Pemasaran. Jakarta: Indeks.

Kotler, Philip. 2007. Manajemen Pemasaran, Analisis Perencanaan, Pengendalian. Jakarta: Salemba Empat.

Kotler, Philip dan Kevin Lane Keller. 2008. Manajemen Pemasaran. Jakarta: Indeks.

Kuingu, Yerry. 2014. Pengaruh Faktor Pelayanan Farmasi Terhadap Keputusan Beli Obat Ulang Pasien Rawat Jalan Di Instalasi Farmasi RSUD Undata Palu. Tesis. Program Pascasarjana Universitas Hasanudin, Makassar.

Listyarso, Andi. 2005. Pengaruh Strategi Pemasaran Terhadap Kinerja Pemasaran Dan Kinerja Perusahaan Dengan Persaingan Sebagai Variabel Moderating. Tesis. Program Pascasarjana Universitas Diponegoro, Semarang.

Machfoedz, Mahmud. 2005. Pengantar Pemasaran Modern. Yogyakarta: UPPAMP YKPN. Martiningsih, Dwi. 2008. Pengaruh Metode Pembayaran Kepada Dokter Keluarga Terhadap Efisiensi Biaya Dan Kualitas Pelayanan. Tesis. Program Pascasarjana Universitas Sebelas Maret, Surakarta.

McKenna. R, 2004. Relationship Marketing: Successful Strategies for the Age of the Customer Reading. Massachusetts: Addison-Wesley Publishing Company.

Menon, Anil, et al. 1999. Antecedents and Consequences of Marketing Strategy Making: A Models and A Test. Journal of Marketing. 63:18-40.

Moleong, Lexy J. 2010. Metodologi Penelitian Kualitatif. Bandung: Remaja Rosdakarya. Mowen, John,C. Minor, M. 2008. Perilaku Konsumen. Jakarta: Erlangga.

Purnama, Nursya'bani. 2006. Manajemen Kualitas: Perspektif Global.Yogyakarta: Ekonisia. Rambat, Lupiyoadi dan A. Hamdani. 2006. Manajemen Pemasaran Jasa. Jakarta: Salemba Empat 
Schiffman, Leon dan Leslie Lazar Kanuk. 2008. Perilaku Konsumen. Jakarta: Indeks Sriwijayani, Tri Novi. 2008. Pengaruh Bauran Pemasaran Terhadap Keputusan Konsumen Memiliki Kartu Kredit BRI (Studi kasus Pada BRI Kantor Cabang Solo Slamet Riyadi). Tesis. Program Pascasarjana Universitas Sebelas Maret, Surakarta.

Sugiyono. 2010. Metode Penelitian Kuantitatif Kualitatif \& RND. Bandung: Alfabeta.

Swasta, Basu, dan Irawan. 2008. Manajemen Pemasaran Modern. Yogyakarta: Liberty.

Swastha, Basu. 2009. Manajemen Penjualan. Yogyakarta: BPFE.

Tjiptono, Fandy dan Gregorius Chandra. 2012 Pemasaran Strategik. Yogyakarta: Andi.

Prima. Yogyakarta: Andi. . 2012. Service Management Meningkatkan Layanan

Tjiptono, Fandy. 2008. Strategi Pemasaran. Yogyakarta: Andi.

Wicaksono, Deddy Setyawan. 2010. Analisis Kepuasan Pengguna Jasa Transportasi Taksi Untuk Meningkatkan Loyalitas (Studi Pada PT. Blue Bird Pusaka Di Semarang). www.eprints.undip.ac.id

Widyaswati, Rahmatya. 2010. Analisis Faktor-Faktor Yang Mempengaruhi Kepuasan Sehingga Tercipta Word Of Mouth Yang Positif Pada Pelanggan Speedy Di Semarang. www.eprints.undip.ac.id

Utami, Woro. 2014. Pengaruh Kualitas Layanan Harga, Varian Obat dan Fasilitas Terhadap Kepuasan pelanggan Apotek Yakersuda Bangkalan. Jurnal NeO-Bis .8(1). 